\title{
Informação ou resíduo? Panfletagem no Município de Feira de Santana, Bahia, Brasil
}

\section{Denise Costa Rebouças Lauton ${ }^{1}$, Virginia de Jesus Nunes ${ }^{2}$ e Denise Pastore de Lima ${ }^{3}$}

\author{
${ }^{1}$ Instituto Federal de Educação, Ciência e Tecnologia da Bahia. Estrada Vicinal para \\ Tenda, S/№. Barro Vermelho. Seabra-BA, Brasil (CEP 46900-000). E-mail: \\ deniselauton@yahoo.com.br. \\ ${ }^{2}$ Universidade Estadual de Feira de Santana. Av. Transnordestina, S/No. Novo \\ Horizonte. Feira de Santana-BA, Brasil (CEP 44036-900). \\ ${ }^{3}$ Universidade Tecnológica Federal do Paraná. Av. Sete de Setembro, 3.165. \\ Rebouças. Curitiba-PR, Brasil (CEP 80230-901).
}

Resumo. A panfletagem, embora venha a ser um mecanismo de marketing eficiente para muitas empresas, pode acentuar um grande problema socioambiental, que é o acúmulo de resíduo sólido. Resíduos sólidos ao serem lançados em via pública causam diversos problemas envolvendo a saúde pública e ambiental. No Município de Feira de Santana a panfletagem parece ser um mecanismo de marketing bastante utilizado, desprovido de orientações de produção ou uso, sem regulamentação ambiental. Este trabalho foi proposto objetivando entender a contribuição da panfletagem na divulgação de produtos e serviços e na composição de resíduos sólidos no município de Feira de Santana. Para tanto, utilizou-se de uma avaliação local com intuito de observar a atitude dos munícipes de Feira de Santana que recebem e distribuem panfletos, dando maior suporte às discussões, e de questionário do tipo auto-preenchido de forma on-line para registrar a percepção destes. No total, 142 pessoas participaram da pesquisa que aponta que a panfletagem é utilizada no município e que esta contribui para o aumento no volume de resíduos sólidos, assim como, pelo seu descarte inadequado, favorece a poluição visual, enchentes e proliferação de vetores. Dos munícipes participantes da pesquisa 99,3\% dizem receber panfletos e alegam receber com frequência. Embora os participantes leiam os panfletos recebidos, muitos não utilizam para apoio no momento das compras $(56,03 \%)$. Todos $(100 \%)$ alegam já terem encontrado panfletos descartados em via pública. Conscientes dos danos, uma significativa parcela dos participantes $(70,5 \%)$ não considera a panfletagem indispensável para fomento do comércio e indicam a internet e as redes sócias como meio prático para adquirir informação. Com estes dados, percebe-se a necessidade da regulamentação da panfletagem no município e do fomento de trabalhos de conscientização que

Recebido

$21 / 02 / 2020$

Aceito

$13 / 06 / 2020$

Disponível on line $16 / 06 / 2020$

Publicado

$31 / 08 / 2020$

Acesso aberto

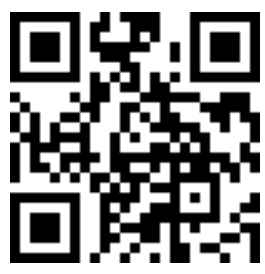

ORCID

(D) 0000-0002-5713-0557 Denise Costa Rebouças Lauton

D 0000-0002-8004-7874

Virginia de Jesus

Nunes

ISSN 2359-1412/RBGAS-2020-0056/2020/7/16/4/501

Rev. Bras. Gest. Amb. Sustent.

http://revista.ecogestaobrasil.net 
tenham como intuito a redução da quantidade de panfletos oferecidos e lançados em via pública.

Palavras-chave: Folhetos; Marketing; Percepção ambiental; Resíduo sólido.

Abstract. Information or residue? Pamphletion in the Municipality of Feira de Santana, Bahia, Brazil. Pamphleting, although it will become an efficient marketing mechanism for many companies, can accentuate a major socio-environmental problem, which is the accumulation of solid waste. Solid residue when launched on public roads causes several problems involving public health and environmental. In the municipality of Feira de Santana, pamphletion seems to be a widely used marketing mechanism, devoid of production or use guidelines, without environmental regulation. This work was proposed objectifying understand the contribution of pamphletion on the publicizing of products and services and in the composition solid residue the municipal of Feira of Santana. To do so, a local evaluation was used to observe the attitude of the residents of Feira de Santana who receive and distribute pamphlets, giving more support to the discussions, and a self-completed self-filled questionnaire online to register the perception of the residents. The in total of 142 residents participated in the survey, which indicates that the pamphletion is used in the municipality and that this contributes to the increase in the amount of solid residue, as well as, due to its inadequate disposal, it favors visual pollution, floods and vector proliferation. The of residents participating in the survey, $99.3 \%$ said they received pamphlets and claimed to receive frequently. Although participants read the pamphlets received, many do not use them for support at the time of purchases (56.03\%). All (100\%) claim they have already found pamphlet discarded on public roads. Conscious of the damages, a significant percentage of the participants $(70.5 \%)$ do not consider pamphletion necessary to foster trade and indicates the internet and the social networks as a practical means to acquire information. With these data, it is noticed the need of the regulation of the pamphletion in the municipality and the promotion of awareness works that aim to reduce the amount of leaflets offered and launched on public roads.

Keywords: Flyers; Solid residue; Marketing; Environmental perception.

\section{Introdução}

Panfletos, folhetos, folders, flyers e encartes são alguns mecanismos de marketing bastante utilizados quando se quer atrair a atenção do público nas cidades. Como são de fácil manuseio e de baixo custo de produção, estas mídias são utilizadas para atingir um grande número de pessoas em pouco tempo (Lino et al., 2013). Mas, pelo mau uso de quem os distribui e recebe pelas ruas, são sinônimo de transtorno e de acúmulo de
0000-0002-8738-5219

Denise Pastore de

Lima 
resíduos, já que, com frequência, são descartados em locais inadequados (Ma e Reis, 2011). Em muitos municípios, não há regulamentação limitando a produção e distribuição destes materiais que são, com frequência, descartados em via pública e contribuem para o aumento dos resíduos sólidos nos municípios (Soledade e Anjos, 2014).

0 aumento na geração de resíduos sólidos tem várias consequências negativas, custos cada vez mais altos para coleta e tratamento do resíduo, dificuldade para encontrar áreas disponíveis para sua disposição final, além do grande desperdício de matéria-prima (Prado e Matos, 2014). Quando os resíduos são dispostos em locais inadequados ou a coleta é falha, estes contaminam e degradam o ambiente, favorecem a proliferação de vetores transmissores de doenças, entopem redes de drenagem urbana e podem causar enchentes. Os transtornos ocasionados pelos resíduos gerados pela população constituem em um grande problema ambiental, de saúde pública e social (Jacobi e Besen, 2011; Gouveia, 2012; Oliva Junior e Freire, 2013).

Segundo a Organização das Nações Unidas (ONU), 5,2 milhões de pessoas morrem a cada ano devido às enfermidades vinculadas aos resíduos sólidos. Dado alarmante que demonstra a necessidade de se minimizar a geração de resíduos sólidos e dar um tratamento adequado ao resíduo gerado, reciclando e reutilizando-o (Campos, 2012; Gouveia, 2012). De acordo com a Política Nacional de Resíduos Sólidos - PNRS (Lei no $12.305 / 10$ ), a redução na geração de resíduos sólidos é a prioridade para seu manejo no Brasil. Para tanto, deve-se aliar desenvolvimento econômico as questões socioambientais adotando, para este fim, novas práticas que minimizem a produção de resíduos sólidos (Schossler e Morigi, 2011; Carvalho, et al., 2015).

A panfletagem contribui para aumento no volume de resíduos sólidos gerados nas cidades (Siqueira e Assad, 2015). Diversos autores (Ma e Reis, 2011; Bedran, 2013; Siqueira e Assad, 2015) apontam alternativas sustentáveis para mitigar estes impactos sem comprometer os objetivos de marketing de divulgar marcas, produtos e serviços para aumento nas vendas. Diante da interatividade moderna e sociedade midiática, as redes sociais, como o Facebook, o WhatsApp e as revistas virtuais, são frequentemente sugeridas como opção de Marketing, pois possuem amplo alcance, atingem um número grande de pessoas de forma rápida e eficiente, proporcionam aumento nas vendas e não geram os danos citados pelo método de panfletagem tradicional impressa, além de possuir baixo custo (Cardoso e Pinto, 2011; Ma e Reis, 2011). A propaganda boca-a-boca (Bentivegna, 2002) e a panfletagem sustentável (Siqueira e Assad, 2015) também são sugeridas como alternativas ao menos para amenizar os impactos e reduzir a geração de resíduos sólidos.

De intensa atividade econômica, a cidade de Feira de Santana, localizada no Estado da Bahia, é um importante polo comercial. Para fomentar o poder de compra e forte comércio, os empreendedores investem na panfletagem como ferramenta de marketing para divulgar seus produtos e serviços. Neste trabalho discute-se se o ato da panfletagem no Município de Feira de Santana, para propaganda de propósito comercial e econômico, sobrepõe os problemas ambientais, sociais e de saúde pública que podem ser ocasionados quando descartados inadequadamente. Portanto, este trabalho tenta entender a contribuição da panfletagem na divulgação de produtos e serviços e na composição de resíduos sólidos do Município de Feira de Santana, segundo percepção dos seus munícipes, registrando estratégias alternativas ao uso deste mecanismo de propaganda. Sabe-se que a percepção ambiental dos munícipes é um sinalizador dos principais problemas sentidos pela comunidade. Utilizou-se desta percepção para entender e retratar a questão da panfletagem no município, já que, para uma gestão mais efetiva do município, é necessário considerar a percepção ambiental de seus cidadãos (Lacerda et al., 2010; Rodrigues et al., 2012), pois uma das dificuldades de protegê-lo está na existência de diferentes percepções e valores, proposição já ressaltada pela UNESCO em 1973. Portanto, a utilização dos dados deste trabalho pode consistir em uma importante ferramenta de gestão. A discussão sobre a contribuição da panfletagem no aumento do volume de 
resíduos sólidos e na intensificação de impactos socioambientais se faz essencial para mudança de atitudes e concepções e, consequentemente, minimização de impactos e melhor gestão municipal.

\title{
Revisão da literatura
}

\section{Resíduo Sólido}

Os resíduos sólidos possuem várias denominações, naturezas, origens e composições (Jacobi e Besen, 2011). A Associação Brasileira de Normas Técnicas (ABNT), a partir da NBR 10004:2004, define resíduos sólidos como:

\begin{abstract}
Resíduos nos estados sólido e semi-sólido, que resultam de atividades de origem industrial, doméstica, hospitalar, comercial, agrícola, de serviços e de varrição. Ficam incluídos nesta definição os lodos provenientes de sistemas de tratamento de água, aqueles gerados em equipamentos e instalações de controle de poluição, bem como determinados líquidos cujas particularidades tornem inviável o seu lançamento na rede pública de esgotos ou corpos de água, ou exijam para isso soluções técnicas e economicamente inviáveis em face à melhor tecnologia disponível (ABNT, 2004).
\end{abstract}

As características dos resíduos sólidos podem variar em função de aspectos sociais, econômicos, culturais, geográficos e climáticos (Zanta e Ferreira, 2017). De modo geral, os resíduos sólidos são constituídos de substâncias facilmente degradáveis, como restos de comida, cascas de frutas, animais mortos e excrementos, moderadamente degradáveis, como papel, papelão e outros produtos celulósicos, dificilmente degradáveis, como couro, madeira, borrachas, plásticos, e não degradáveis, como vidro, cinzas, terra e areia. Os resíduos podem ser classificados de acordo com sua origem em resíduo doméstico ou residencial, resíduo comercial, resíduo público, resíduo domiciliar especial e resíduo de fontes especiais. Os resíduos sólidos também são classificados quanto ao risco à saúde pública e ao meio ambiente em resíduos classe I (perigosos) e resíduos classe II (não perigosos) - que é subdividido em inerte e não inerte (NBR 10004:2004). Estas caracterizações auxiliam a tomada de decisão quanto a separação destes resíduos, armazenamento e disposição final (Machado e Henkes, 2016).

A produção de resíduos nas cidades brasileiras é um fenômeno inevitável, que ocorre diariamente, cuja composição e quantidade depende do tamanho populacional e desenvolvimento econômico (Grippi, 2006). Alterações no estilo de vida e nos modos de produção e consumo da população aliada a ausência de políticas públicas provocam aumento na geração de resíduos sólidos, tanto em quantidade como na variedade, principalmente nos grandes centros urbanos (Demajorovic, 1995; Campos, 2012). Além do incremento em volume, os resíduos produzidos passaram a abrigar em sua composição elementos sintéticos e perigosos aos ecossistemas e à saúde humana (MMA, 2005). Os resíduos sólidos constituem em um grave problema quando mal gerenciados ou descartados inadequadamente e favorecem a proliferação de micro vetores de agentes etiológicos como, amebíase, salmoneloses, helmintoses e servem como criadouros e esconderijos para macro vetores como ratos, que estão envolvidos na transmissão da peste bubônica e leptospirose, e insetos que podem transmitir a leishmaniose, doença infecciosa altamente perigosa (Besen et al., 2010; Oliva Junior e Freire, 2013). Os resíduos sólidos também entopem bueiros, contaminam cursos d'água e lençóis freáticos, favorecem questões sociais ligadas aos catadores de lixo e as atividades turísticas (Mesquita Júnior, 2007; Gouveia, 2012). Os transtornos ocasionados pelos resíduos gerados constituem em um grave problema ambiental, de saúde pública e social (Jacobi e Besen, 2011; Gouveia, 2012; Oliva Junior e Freire, 2013). 
De acordo com levantamento direto da ABRELPE (2016) o Brasil produziu em 2016 um total anual de 78,3 milhões de toneladas de resíduos sólidos urbanos, sendo de 71,3 milhões de toneladas o montante coletado e de 7 milhões de toneladas o montante de resíduos que não foram objeto de coleta, tendo um destino impróprio. Uma grande parcela dos resíduos sólidos produzidos atualmente não possui destinação sanitária e ambientalmente adequada (Gouveia, 2012). Estima-se que no Brasil cerca de 63,6\% dos resíduos que são produzidos são dispostos a céu aberto, em lixões, 18,4\% são dispostos em aterros controlados e 13,8\% são encaminhados aos aterros sanitários (Mesquita Júnior, 2007). Segundo Gouveia (2012), a disposição de resíduos em lixões, é uma forma perigosa de lidar com a questão, além de acarretar em problema socioambiental, os resíduos expostos tornam-se altamente contaminantes e vetores de doenças, no entanto, por ser considerado de baixo custo, é uma forma de disposição ainda muito utilizado no Brasil. Do resíduo gerado nas cidades do Brasil, apesar de $30 \%$ a $40 \%$ ser considerado passível de reaproveitamento e reciclagem, apenas 13\% é encaminhado para reciclagem (Silva, 2017). Enquanto a geração de resíduos é mantido em patamares elevados, percebe-se que a reciclagem ainda é incipiente, o que vai de encontro ao que determina a Política Nacional de Resíduos sólidos - PNRS (Lei no 12.305/2010) (Brasil, 2010). Mesmo implantada a mais de oito anos, a PNRS carece de aplicação prática em vários aspectos (Campos, 2012; ABRELPE, 2016). Considerando as limitações das opções de destinação final para os resíduos e que o seu inadequado gerenciamento resulte em impactos ao ambiente e a sociedade, deve-se investir na reciclagem, reutilização e redução (lógica dos três R's) dos resíduos sólidos para minimizar montante produzido e evitar maiores impactos socioambientais (Campos, 2012; Gouveia, 2012). Os dados apresentados demonstram a necessidade da adoção de padrões de produção e consumo mais sustentáveis e da compreensão e disseminação à sociedade dos problemas ocasionados pelos resíduos sólidos para que trabalhos de conscientização e gestão de resíduos sejam mais efetivos nos municípios brasileiros (Jacobi e Besen, 2011; Carvalho et al., 2015).

\section{Panfletagem}

Panfletagem é a entrega de material impresso de extensão máxima de 4 páginas, de fácil leitura e compreensão. Frequentemente o panfleto é distribuído de forma gratuita e em grande quantidade para divulgação e promoção de um bem, produto ou serviço (Christiasen e Bjerre, 2001; Miranda e Konya, 2007). Com a concorrência cada vez mais acirrada, as empresas buscam destaque no mercado para atingir as metas organizacionais (Antón et al., 2011; Correio, 2015). Os panfletos tem sido uma das mídias mais utilizadas e de poderosa propagação para destacar produtos e serviços (Gázquez-Abad e Pérez, 2007; Antón et al., 2011) e por isso são tão utilizadas e importantes para os empreendedores (Miranda e Konya, 2007).

Segundo Schiffman e Kanuk (2000), a sociedade consumidora para ser mantida precisa, a todo momento, ser estimulada através de mecanismos de marketing. A panfletagem é mencionada como um mecanismo assertivo de marketing para fomento e aumento nas vendas (Bronnemann e Siebert, 2005). Os panfletos são utilizados pelos empreendedores para promover novos produtos, anunciar novos serviços, divulgar promoções, dentre outros usos, tendo como objetivo informar, estimular e convencer o consumidor, induzindo-o a compra e utilização do serviço (Miranda e Konya, 2007; Lino et al., 2013). Portanto, a panfletagem é uma ferramenta utilizada para persuadir os consumidores e induzi-los ao consumo de produtos e serviços, ou seja, é um método que tenta alterar o comportamento do consumidor (Medeiros et al., 2009).

Apesar das inúmeras vantagens da utilização da panfletagem para o empreendedor citadas aqui, Gàzquez Adab e Pérez (2007) e Lino et al. (2013), mencionam que poucos trabalhos analisam com precisão a influência e o efeito do uso de folhetos no comportamento de compra ou uso de um serviço por parte do consumidor, averiguando a 
efetividade deste uso. A maioria dos panfletos distribuídos não são aproveitados, sendo descartados logo após o recebimento o que contribui com o aumento do volume de resíduos sólidos e causa um grande desperdício de recurso que envolve corte e derrubada de árvores, desgaste do solo, consumo de água e energia (Soledade e Anjos, 2014). Quando descartados em via pública de forma inadequada, os panfletos contribuem com as enchentes, proliferação de vetores e poluição visual (Ma e Reis, 2011; Silva e Coutinho, 2016). Durante a campanha eleitoral esta situação parece se agravar, há produção de uma quantidade excessiva de folhetos, de "santinhos", que são distribuídos e descartados em via pública (Anjos, 2015), o que vai de encontro ao art. 243, da Lei no 4.737/1965, que institui o Código Eleitoral, e que demonstra a preocupação com o meio ambiente, o qual preconiza:

Art. 243. Não será tolerada propaganda:

$[\ldots]$

VIII - que prejudique a higiene e a estética urbana ou contravenha a posturas municiais ou a outra qualquer restrição de direito; (Brasil, 1965).

Durante o período eleitoral, Farias (2006) compara as cidades a verdadeiros lixões, referindo-se à feição diferenciada que as cidades passam a ter neste período. Ao divulgar balanço eleitoral do lixo recolhido nas ruas de Belo Horizonte, pode-se perceber a dimensão do impacto decorrente dos materiais utilizados durante a propaganda eleitoral (Bedran, 2013). Belo Horizonte produziu cerca de 128 toneladas de resíduos sólidos após primeiro turno das eleições municipais de 2012. Para minimizar impactos socioambientais, a norma eleitoral deve ser modificada no sentido de buscar substituir a produção de panfletos por outras formas de propaganda mais limpas como as veiculadas pela internet, ou estabelecer limites em relação à quantidade de panfletos a ser impressa por candidato e/ou instituir normas que tornem obrigatória a reciclagem pelos partidos do montante de material gasto com a propaganda eleitoral (Soledade e Anjos, 2014). Os panfletos, por mais bem elaborados que sejam, em algum momento serão descartados e contribuirão para o acúmulo de resíduos sólidos. A problemática deve ser tratada com seriedade (Ma e Reis, 2011). Diante dos malefícios que os panfletos podem acarretar às cidades, alguns municípios brasileiros regulamentaram a situação. 0 Município de Belo Horizonte sancionou a Lei no 10.534/2012 (Belo Horizonte, 2012), a qual, em seu art. 55, inciso II, menciona a proibição da distribuição em vias públicas de impressos de qualquer natureza, com intuito de assegurar limpeza urbana. Já o Município de Jacarezinho, no Paraná, sancionou a Lei Complementar no 44/2010, que responsabiliza o empreendedor pela limpeza de seus panfletos dos espaços públicos, mesmo que autorizado para distribuição (Jacarezinho, 2010). Esta lei complementar também exige que estes panfletos tenham a inscrição "Ajude a preservar o meio ambiente: não jogue este impresso em via pública", estes dizeres devem ocupar no mínimo 5\% de uma das suas faces. A prefeitura de Balneário Camboriú, Santa Catarina, através da Lei no 2.558/2006 (Balneário Camboriú, 2006) também permite a distribuição de panfletos com algumas regulamentações. Há indicações de horários e locais específicos para distribuição dos panfletos e também há a indicação da inserção da observação "não jogue no chão - mantenha a cidade limpa reciclável" (dizeres devem ocupar no mínimo 5\% de uma de suas faces) em seus panfletos. Em todos os casos citados, o descumprimento da lei pode gerar advertência, multa e suspenção de autorização para distribuição de panfletos.

Com intuito de amenizar possíveis problemas ocasionados pela panfletagem no Brasil, autores (Ma e Reis, 2011; Siqueira e Assad, 2015) sugerem alternativas ao uso da panfletagem, como a publicidade on line. Os sites e as redes sociais, como Facebook Ads, WhatsApp, e-mails e do Google AdWords, vêm se tornando grandes aliados dos 
empreendedores (Cardoso e Pinto, 2011; Alves Junior e Daolio, 2017). Segundo Siqueira e Assad (2015), além de proporcionarem aumento nas vendas, estes meios de forma interativa e midiática, possibilitam continuidade de relacionamento com os clientes, a custos reduzidos. 0 ato de entregar panfletos apenas para quem está interessado no evento divulgado, inserção de encartes em jornal e revista e a inserção de suportes com folhetos na frente do estabelecimento para retirada de quem tem interesse no anúncio, também minimizam impactos e constituem estratégias de marketing sustentável (Ma e Reis, 2011).

\section{Percepção ambiental}

A percepção ambiental é a tomada de consciência do ambiente pelo homem, é o ato de perceber e compreender o ambiente que se está inserido (Ferrapa, 1996) e extrair informações deste (Rodrigues et al., 2012). Os estudos de percepção constituem em uma visão ímpar por possibilitar compreender melhor as inter-relações da população com o ambiente, suas satisfações, insatisfações, julgamentos e condutas, e tem como intuito descobrir o que falta ou precisa melhorar daquela realidade (Palma, 2005). Conhecer as concepções e particularidades focadas em bases locais pode subsidiar a realização de projetos e ações que atendam às necessidades encontradas e que sejam adequadas àquela realidade propiciando atingir resultados mais satisfatórios nas ações (Carvalho et al., 2012). 0 uso da percepção ambiental da comunidade pode atuar como ferramenta de apoio à gestão do meio ambiente (Bezerra et al., 2008) e subsidiar um processo participativo para uma gestão compartilhada entre poder público e sociedade (Lacerda et al., 2010; Rodrigues et al., 2012). A UNESCO em 1973 já ressaltava que para uma gestão mais efetiva do município é necessário considerar a percepção ambiental de seus cidadãos (Lacerda et al., 2010; Rodrigues et al., 2012), já que uma das dificuldades de protegê-lo está na existência de diferentes percepções e valores.

A percepção ambiental pode ser utilizada nas mais variadas áreas do conhecimento (Palma, 2005). A aplicação de questionários, mapas mentais, representação fotográfica, são algumas, dentre outras, formas de se estudar a percepção ambiental (Faggionato, 2005). A pesquisa em percepção ambiental pode ser utilizada como um possível caminho acerca das áreas verdes públicas, como praças, parques e jardins, já que contribui com informações importantes para a manutenção e multiplicação destes espaços no meio urbano (Costa e Colesanti, 2011). Estudos de percepção ambiental podem ser utilizados para avaliar a degradação ambiental de uma determinada região. Os dados perceptivos permitem realçar e interpretar o processo de degradação, evidenciar a omissão dos órgãos públicos encarregados do licenciamento e monitorar a urbanização (Ferreira, 2001). Metodologias de educação ambiental podem ser propostas utilizando-se de estudos sobre percepção do ambiente, como o caso do Bosque John Kennedy, Araguari em Minas Gerais. Ao considerar as concepções dos seus visitantes, foi possível perceber a necessidade da implantação de um programa de educação e de interpretação ambiental para auxiliar os seus visitantes (Menezes, 2011). A descrição da percepção do sentimento da população em relação ao ambiente representa uma ferramenta estratégica para monitorar e fomentar mudanças de atitudes da população, considerando o pressuposto de que a sensibilização, por meio do conhecimento do sistema ambiental, é condição básica para o envolvimento efetivo dos cidadãos (Bezerra et al., 2008).

\section{Materiais e métodos}

\section{Área de estudo}

Este estudo foi desenvolvido em Feira de Santana ( $12^{\circ} 16^{\prime} 24^{\prime \prime}$ S e $38^{\circ} 57^{\prime} 20^{\prime \prime}$ W), município situado no Estado da Bahia, Brasil, que possui $1.304,425 \mathrm{~km}^{2}$ de área territorial e 556.642 habitantes (IBGE, 2018). Feira de Santana localiza-se em uma zona 
intermediaria entre o litoral úmido e o interior semi-árido na região nordeste (Santo, 2003). Possui clima seco a subúmido com precipitação média anual de $848 \mathrm{~mm}$ e temperatura média anual em torno de $24^{\circ} \mathrm{C}$ (INMET, 2018).

As características pedológicas e geológicas de Feira de Santana favoreceram o aparecimento de inúmeras lagoas e nascentes, fixação da população humana e o desenvolvimento feirense em torno do comercio. A intensa atividade econômica voltada para o comércio e, hoje de forma mais discreta, para pecuária, teve origem em seu primórdio. Somente nas últimas décadas o setor industrial ganhou mais força (Santo, 2003; Queiroz et al., 2004). Como toda colonização por exploração, Feira de Santana expandiu-se sem planejamento urbano e suas consequências são nítidas, inúmeros problemas ambientais e sanitários. Devido a pressão imobiliária e a falta de educação ambiental, muitas das lagoas existentes no município foram ocupadas, contaminadas e aterradas. Feira de Santana na área do meio ambiente dispõe de legislação avançada, entretanto não se efetiva na prática (Queiroz et al., 2004). 0 município ainda carece de um Plano Municipal de Gestão Integrada de Resíduos Sólidos, sua elaboração ainda está em tramitação (Feira de Santana, 2016).

\section{Coleta dos dados}

Primeiro, para levantamento de dados e posterior embasamento da discussão, uma avaliação local foi realizada a fim de se notar a atitude dos munícipes de Feira de Santana que recebem e distribuem panfletos. Fotografias foram tomadas para tanto. Trata-se de uma metodologia inspirada na pesquisa etnográfica, que segundo Silva (2009, p. 175), consiste na "[...] sua circulação no campo, sua observação do campo e sua versão do que aconteceu ali e seus significados". Em um segundo momento e de forma concomitante, esta pesquisa utilizou de questionário do tipo auto-preenchido (Mattar, 2008), em que o participante lê o formulário e o responde diretamente sem a intervenção do entrevistador. Gil (2008) aponta uma série de vantagens e limitações da aplicação de questionários, contudo o questionário é bastante recomendado em pesquisas que visem explorar alguma experiência específica em condições consideradas e atinge um grande número de pessoas em um curto espaço de tempo.

Pode-se definir questionário como a técnica de investigação composta por um conjunto de questões que são submetidas a pessoas com o propósito de obter informações sobre conhecimentos, crenças, sentimentos, valores, interesses, expectativas, aspirações, temores, comportamento presente ou passado etc. (Gil, 2008, p. 121).

Para que fosse possível uma maior abrangência em um curto espaço de tempo para coleta, o questionário foi inserido no Google Forms, plataforma on-line gratuita de construção de formulários, e um link para acesso foi gerado para ser disponibilizado aos participantes da pesquisa de forma on line (link abaixo). Houve divulgação do questionário de abril a maio de 2018 em redes sociais, como o Facebook, o whatsApp, dentre outras. 0 formulário ficou disponível para preenchimento on-line durante todo o período. 0 questionário foi do tipo on-line para facilitar a conclusão da pesquisa, já que não havia a necessidade da impressão dos questionários e os participantes poderiam participar a qualquer momento e em qualquer ambiente. Embora o método apresente diversas vantagens, este também é considerado excludente, ao não incluir pessoas com dificuldade de leitura e acesso à internet e as redes sociais, e também não permitir interações entre entrevistador e entrevistado (Vieira et al., 2010). 0 questionário possuía 24 questões, contendo questões fechadas, dependentes e abertas (Gil, 2008), sendo 12 de resposta obrigatória. As questões foram baseadas nas observações das atitudes dos munícipes de Feira de Santana perante a panfletagem. Nesta pesquisa, os nomes dos colaboradores não são divulgados. As informações obtidas são utilizadas apenas para fins acadêmicos de 
pesquisa e divulgação do conhecimento científico. Link para acesso ao questionário: https://docs.google.com/forms/d/1EwKKVWK6RfxUsVRH22S7VZYcu48N3cIuuHdaro IWZ3w.

\section{Análise dos dados}

No final do mês de maio, inativou-se a planilha para que não fosse mais possível receber respostas de possíveis participantes da pesquisa. Os dados foram exportados do Google Forms em formato Excel, triados, mantendo apenas os participantes que responderam residir ou já ter residido em Feira de Santana, já que o objetivo era considerar apenas informações referentes ao município.

A análise dos dados foi realizada de forma quantitativa e qualitativa. Quantitativa, utilizando técnicas de estatística descritiva, distribuição de frequência. A distribuição de frequência foi realizada em todas as questões elencadas. E qualitativa visando à compreensão interpretativa das respostas dos entrevistados. Também foram inseridas, provenientes das questões abertas, frases transcritas ipsis litteris, transcritas exatamente igual ao que foi escrito pelo participante da pesquisa, inclusive considerando erro de grafia (Gil, 2008), com o intuito de complementar a compreensão das percepções avaliadas.

\section{Resultados e discussão}

\section{Panfletagem no Município de Feira de Santana (Inspiração Etnográfica)}

A panfletagem (Figura 1) vem sendo uma estratégia de marketing cada vez mais utilizada pelos empreendedores do município de Feira de Santana (Figura 2) para promover bens ou serviços que oferecem visando o lucro. Os panfletos são de diferentes modelos, tamanhos, espessuras e gramaturas (Figura 3). Diversos setores do comércio utilizam deste tipo de marketing, setor de festas e eventos, setor de prestação de serviços, de produtos de consumo, imobiliário, setor eleitoral, científico, dentre outros (Figura 4). No município de Feira de Santana a panfletagem parece não ser direcionada a um público específico (Figura 5). Pode-se observar no comércio crianças recebendo panfletos com anúncios de eventos proibidos para sua faixa etária, evento que, possivelmente, não poderiam frequentar (Figura 6). Ao receber os panfletos, muito dos feirenses, com frequência, não leem ou se quer sentem curiosidade para verificar do que se trata o anúncio, e lançam os panfletos nas vias públicas de forma inadequada, mesmo havendo lixeiras próximas dos pontos de panfletagem ou podendo guardá-los para descarte posterior. Circunstância que pode ser verificada ao se fazer uma simples observação das ruas do município (Figura 7). Este comportamento contribui com o aumento da poluição ambiental bem como visual do município. Tal ato pode promover o entupimento dos bueiros, comprometer o escoamento das águas pluviais e culminar em enchentes. Estas atitudes parecem derivar da falta de conscientização da população feirense quanto às questões ambientais. Atitudes que poderiam ser minimizadas se fossem fortalecidas e/ou elaboradas políticas públicas voltadas para educação e conscientização da população. Sabe-se que a educação ambiental, ao informar e apontar possibilidades, transforma realidades (Sorrentino et al., 2005).

Os panfletistas ao entregarem vários panfletos por munícipe, geralmente com mesmo anúncio, contribuem para que mais resíduos sejam descartados, intensificando o problema dos resíduos sólidos no município (Figura 8). Esta atitude parece não garantir os benefícios apontados pelos empreendedores ao adotar a técnica, que consistem na popularização da informação e aumento nas vendas e, ao contrário, pode causar má impressão ao cliente e comprometer a imagem do empreendedor e, consequentemente, do seu negócio. No entanto, os empreendedores investem cada vez mais nessa técnica de merchandising no município de Feira de Santana (Figura 9) por terem a sensação de um marketing eficiente. Esse comportamento de distribuição dos panfletistas parece derivar 
da necessidade de se atingir metas diárias de distribuição de panfletos impostas pelos contratantes e da falta de orientação adequada ao serem contratados para o serviço. Os contratantes devem rever sua política de merchandising e de contratação do serviço para que seus objetivos sejam alcançados e os danos ambientais sejam minimizados.

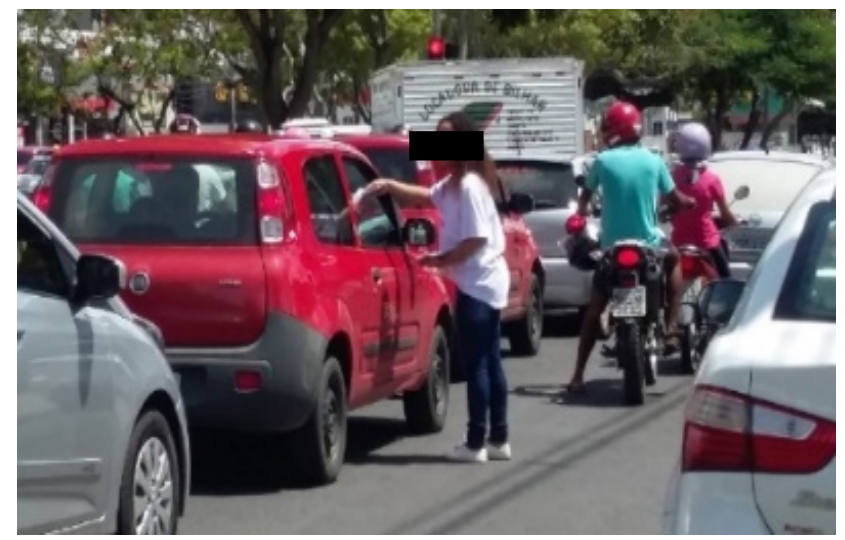

Figura 1. Panfletagem na sinaleira do Município de Feira de Santana, Bahia.

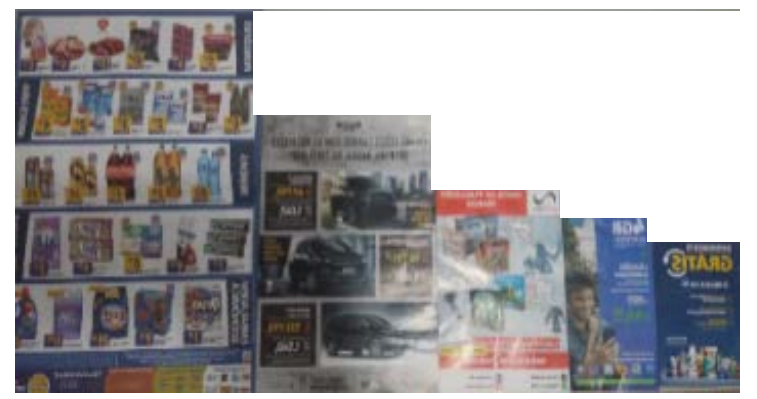

Figura 3. Panfletos de diferentes modelos, tamanhos, espessuras e gramaturas.

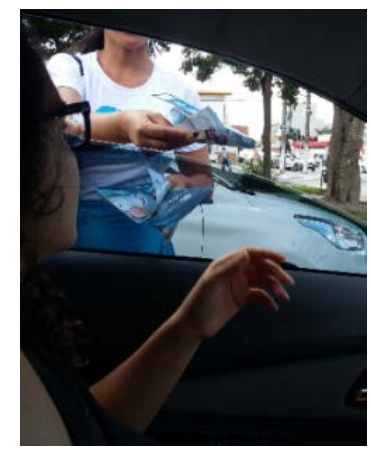

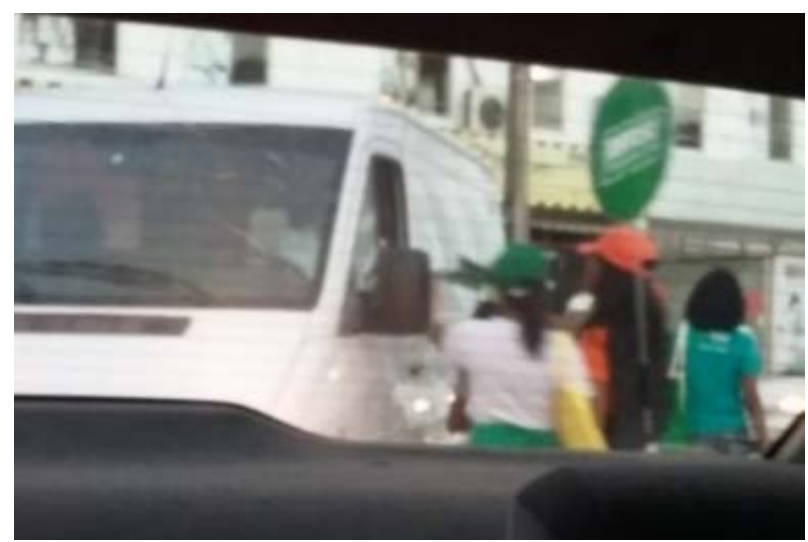

Figura 2. Equipe de panfletagem personalizada na sinaleira do Município de Feira de Santana, Bahia.

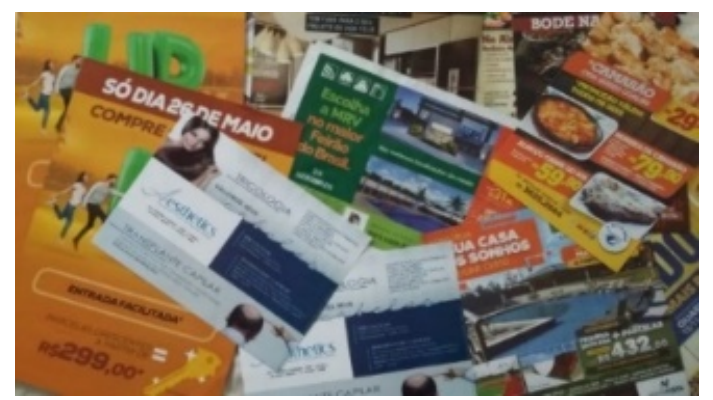

Figura 4. Panfletos de vários setores distribuídos no Município de Feira de Santana, Bahia.

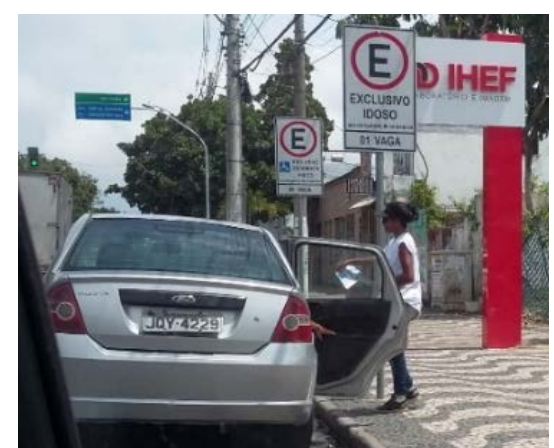

Figura 5. Panfletagem não direcionada no Município de Feira de Santana, Bahia.

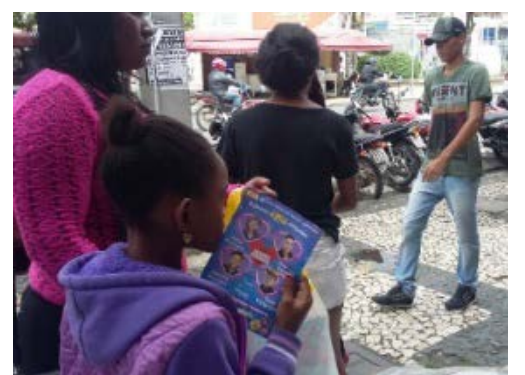

Figura 6. Panfletagem não direcionada no Município de Feira de Santana, panfleto recebido por uma criança.

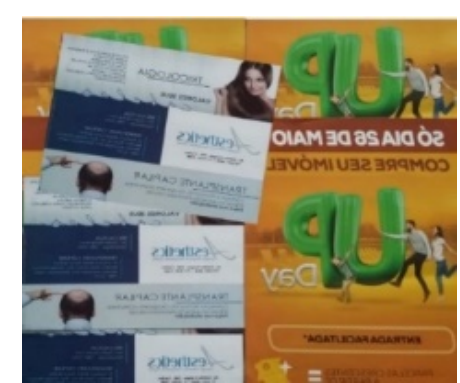

Figura 7. Panfletos com anúncios repetidos distribuídos no Município de Feira de Santana, Bahia. 

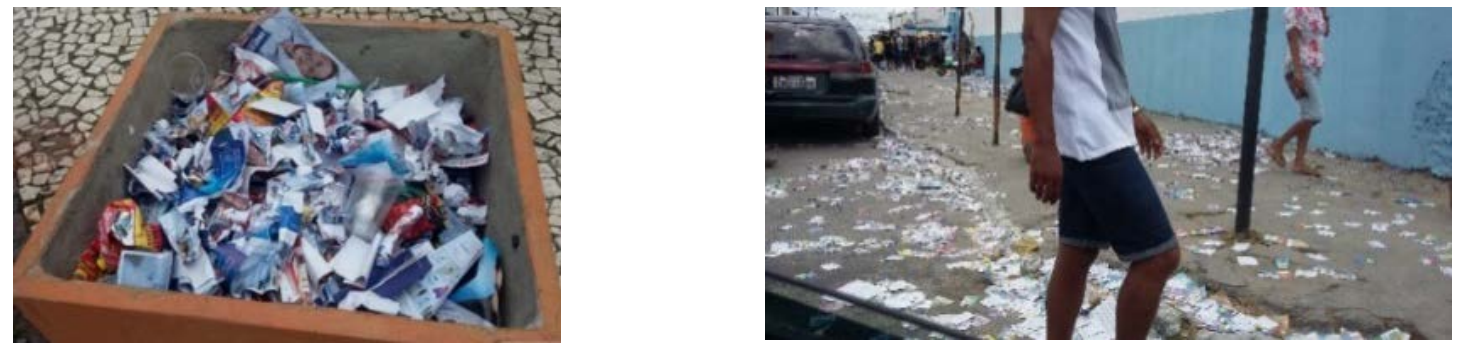

Figura 8. Panfletos amassados e jogados em via pública no Município de Feira de Santana, Bahia.
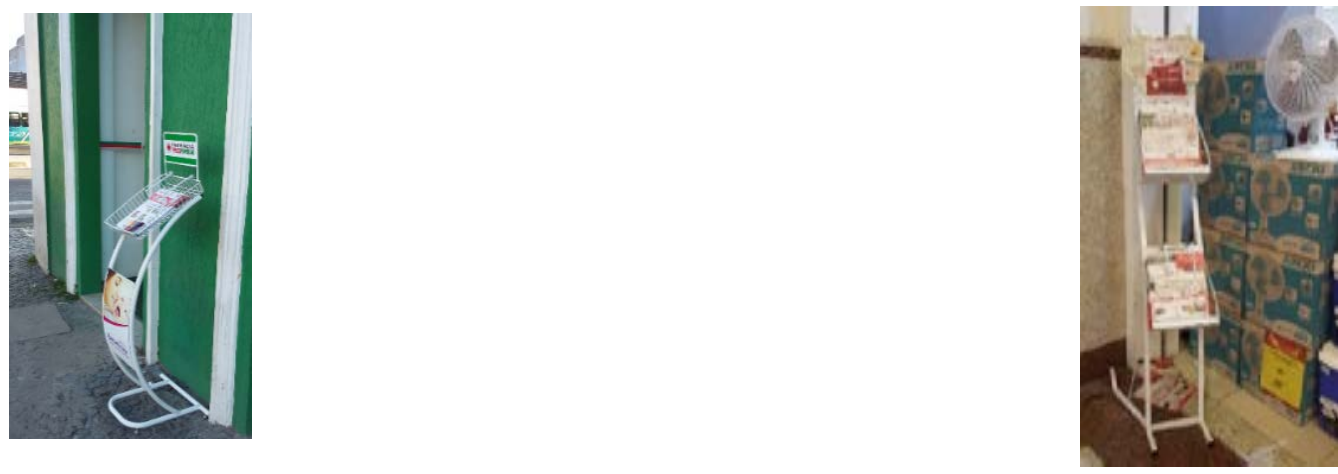

Figura 9. Panfletos expostos em ponto fixo em frente ao ponto comercial.

\section{Perfil dos Participantes da Pesquisa}

0 questionário on line foi preenchido por 142 colaboradores maiores de 18 anos de idade que residem ou já residiram no município de Feira de Santana, Bahia. Deste total, $65 \%$ é representado por mulheres e $35 \%$ por homens. Dos respondentes, $52,81 \%$ possuíam idade entre 18 a 30 anos, 35,21\% entre 31 a 45 anos e 11,97\% acima de 45 anos. Quanto a escolaridade, 69\% dos respondentes alegaram cursar ou já terem cursado pósgraduação, $47,89 \%$ o ensino superior, $18,31 \%$ o ensino médio e $2,11 \%$ o ensino fundamental. Conforme a descrição acima, os colaboradores possuem perfis variados, característica importante já que o objetivo foi considerar a percepção ambiental de um público diverso sobre a panfletagem no município.

Panfletagem como estratégia de marketing no Município de Feira de Santana

Ao serem questionados se já receberam panfletos, 99,3\% dos munícipes participantes confirmam terem recebido e $0,70 \%$ alegam nunca terem recebido panfletos. Dos que receberam, $41,84 \%$ dizem receber toda semana, $17,73 \%$ todos os dias, $14,89 \%$ todo mês e $25,53 \%$ dizem receber esporadicamente. Indagou-se também qual foi a atitude do munícipe ao receber os panfletos (figura 10), nenhum dos entrevistados optou pelas alternativas da questão: lê e joga no chão; não lê e joga no chão. Pelo que foi observado no município, muitos panfletos são jogados em espaço público, contudo nenhum dos respondentes indicou jogar os folhetos no chão. Este resultado pode ser um reflexo do público participante da pesquisa, só participaram aqueles que tinham acesso às redes sociais e a internet o que de certa forma restringe o público participante a um determinado segmento socioeconômico, embora para se ter uma visão abrangente sobre o fato fosse interessante se conhecer a percepção de diferentes segmentos socioeconômicos. Este resultado também pode ter derivado da insegurança dos participantes quanto ao julgamento social de suas respostas, embora a pesquisa considere seu anonimato. 
Qual a atitude ao receber um panfleto?

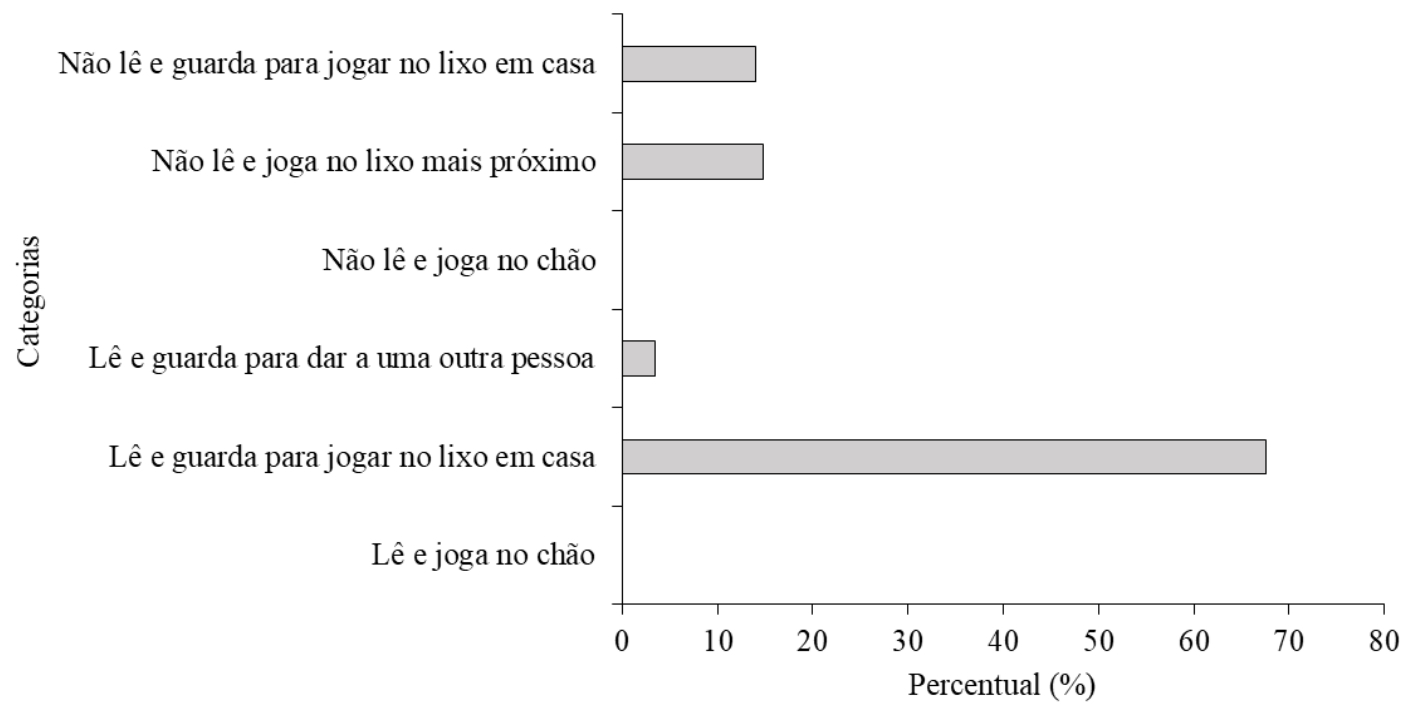

Figura 10. Respostas a pergunta "Qual a atitude ao receber um panfleto?" em percentagem.

Os resultados expostos acima demonstraram que os empreendedores do município de Feira de Santana investem em panfletagem como estratégia de marketing, já que a maioria dos participantes recebem, com frequência, panfletos publicitários. Embora uma parcela significativa dos participantes leia os anúncios contidos nos panfletos e os utilize (figura 11), antes de descartá-los, análises são necessárias para mensurar sua efetividade no aumento das vendas. Não há trabalhos no município que citem sua efetividade como estratégia de marketing e se o investimento na produção e distribuição dos panfletos compensa os gastos. Gázquez Abad e Pérez (2007) e Lino et al. (2013) discutem, para outros municípios, indícios da influência da panfletagem na decisão de compra e mudança de comportamento do consumidor, embora reconheçam a dificuldade nesta mensuração. Segundo Gázquez Abad e Pérez (2007) a influência vai estar vinculada também ao tipo de anúncio contido no folheto. Segundo estes, folhetos promocionais tendem a ser mais atrativos e efetivos.

\section{Utiliza os panfletos recebidos?}

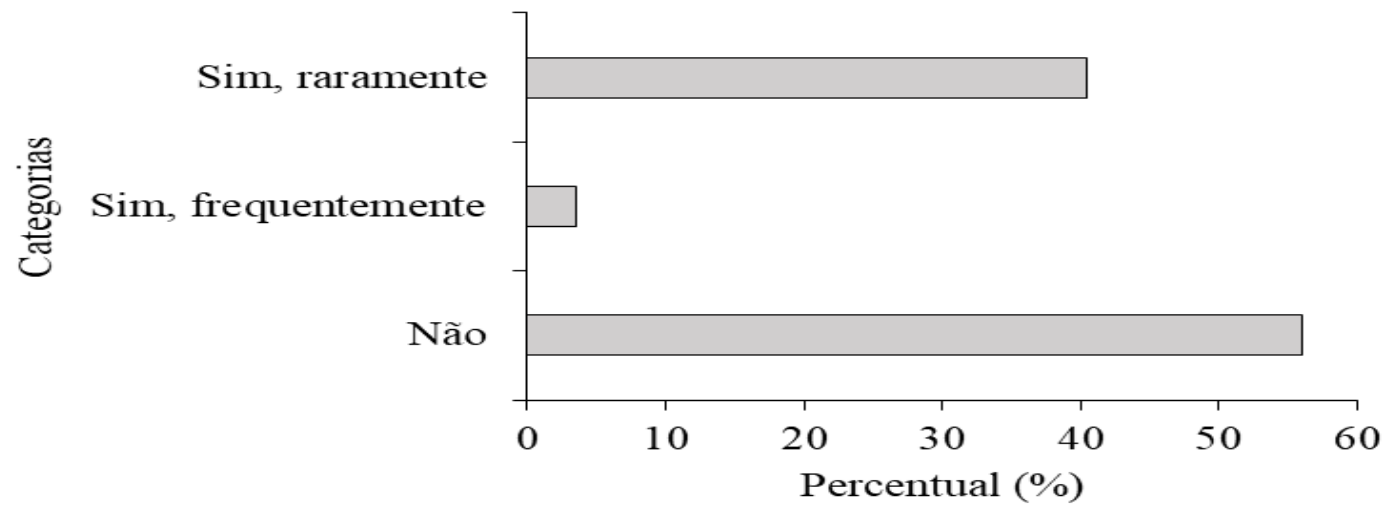

Figura 11. Respostas a pergunta “Utiliza os panfletos recebidos?" em percentagem. 
Dos participantes da pesquisa que recebem panfletos com anúncios repetidos de uma única vez, 76,98\% dizem receber em torno de duas unidades de panfletos contendo anúncios iguais, $17,99 \%$ em torno de quatro unidades, 1,44\% em torno de cinco unidades e 3,6\% mais de cinco unidades em uma única vez. Também respondem que recebem panfletos, mais frequentemente, ao andar pela cidade $(76,06 \%)$, no carro ou sinaleira $(22,53 \%)$ e em suas residências $(1,41 \%)$. Ao serem questionados se encontram panfletos na caixa de correio de suas residências, $77,5 \%$ dos colaboradores dizem encontrar e $22,53 \%$ dizem não encontrar. Ao considerar o número elevado de participantes que recebem anúncios repetidos e os locais variados que estes recebem os panfletos, pode-se inferir o cunho não direcional desta ferramenta de marketing em Feira de Santana. Segundo Schmidt e Bjerre (2003), os panfletos nem sempre são distribuídos de forma personalizada pelos ofertantes e, em alguns casos, são colocados nas caixas de correio, depositados nos portões das residências e nos para-brisas dos carros. Este não direcionamento dos programas de merchandising altera seus objetivos e, consequentemente, reduz sua efetividade.

Embora Siqueira e Assad (2015) reconheçam a importância da panfletagem como ferramenta de marketing, estes destacam seu caráter efêmero, pontual, e ressaltam que a panfletagem vai de encontro a lógica da sustentabilidade, já que reconhecem a necessidade do desenvolvimento, neste século, de uma cultura de geração mínima de resíduos. Ma e Reis (2011) validam a utilização da internet e redes sociais como meios de publicidade efetivos para fomento das vendas e alternativos ao uso da panfletagem impressa. Estes, dentre outros autores (Bentivegna, 2002; Cardoso e Pinto, 2011; Alves Junior e Dalio, 2017), consideram a publicidade on line um mecanismo prático, de baixo custo, de amplo alcance e que não necessita de impressões para sua divulgação, o que evita posterior descarte e geração de resíduos, minimizando possíveis impactos ambientais.

\section{município \\ Contribuição da panfletagem na composição dos resíduos sólidos do}

Quando questionados se já observaram panfletos jogados nas ruas de Feira de Santana, $100 \%$ dos participantes confirmaram ter observado, destes $75,35 \%$ dizem observar sempre, $23,94 \%$ as vezes e $0,70 \%$ dizem observar raramente. Sobre a quantidade de panfletos observados no chão, 73\% dos respondentes acham esta quantidade alta e $26,95 \%$ acham baixa. As respostas expostas aqui corroboram com o observado diariamente no município e também revelam o comportamento dos munícipes de Feira de Santana ao receberem os panfletos distribuídos: uma grande parcela dos munícipes descartam os panfletos recebidos de forma inadequada perturbando o equilíbrio do meio e contribuindo com o aumento no volume de resíduos sólidos no município. Segundo Prado e Matos (2014), o aumento na geração de resíduos sólidos pode acarretar em dificuldades para o município, custo elevado para coleta e tratamento dos resíduos sólidos e dificuldade para encontrar áreas disponíveis para sua disposição final. 0 descarte inadequado dos folhetos intensifica o problema, pois entopem redes de drenagem urbana, causam enchentes, favorecem a proliferação de vetores transmissores de doenças, e comprometem o meio ambiente (Jacobi e Besen, 2011; Gouveia, 2012; Oliva Junior e Freire, 2013). Outro problema ocasionado pelo descarte inadequado dos folhetos é a poluição visual, que prejudica o bem-estar e, consequentemente, compromete a saúde da população (Castanheiro, 2009; Silva e Coutinho, 2016). Segundo Soledade e Anjos (2014), o problema da panfletagem não se resume somente ao seu descarte, a produção de folhetos envolve uso de água e madeira e desgaste do solo, recursos essenciais à vida. Há consumo de, aproximadamente, 100 mil litros de água e 20 árvores a cada tonelada de papel produzido, com estes dados é possível perceber o impacto da produção dos impressos no ambiente e na sociedade (dados do Tribunal Superior Eleitoral relativos às eleições de 2012). 
A ausência de regulamentação e de um plano de resíduos sólidos no município de Feira de Santana potencializa a intensificação do problema. O Município de Balneário Camboriú, em Santa Catarina, adota atitude diferente para minimizar os impactos da panfletagem. O município sancionou a Lei $\mathrm{n}$ - 2.558/2006, que permite a distribuição de panfletos pelos empreendedores com algumas restrições (Balneário Camboriú, 2006). Há na lei indicações de horários e locais específicos para distribuição dos panfletos e também há a indicação da inserção da observação: "não jogue no chão - mantenha a cidade limpa reciclável", dizeres que devem ocupar no mínimo $5 \%$ de uma de suas faces. 0 descumprimento desta lei pode gerar penalidades.

As consequências negativas da produção e do descarte inadequado dos panfletos não devem ser compensadas pelos "benefícios" imprecisos gerados com seu uso como ferramenta de marketing no município de Feira de Santana. Atitudes devem ser adotadas para sanar ou minimizar impactos. Ma e Reis (2011), apontam a internet e as redes sociais como ferramentas de merchandising simples, práticas e mais baratas do que a panfletagem impressa. Bentivegna (2002) aponta o boca-a-boca virtual como alternativa mais convincente, especifica e menos onerosa para conseguir aumento nas vendas, já que o processo de panfletagem além de envolver gasto com produção do material impresso, também envolve contratação de panfletistas para distribuição. Embora, no município de Feira de Santana a contratação destes panfletistas não pareça acarretar em elevado custo para o contratante, já que os contratados não possuem vínculo empregatício e a diária é paga em valores, relativamente, baixos.

\section{Atitudes e percepções dos munícipes de Feira de Santana sobre a panfletagem}

Os munícipes participantes foram questionados sobre a sua atitude ao ver o lixo no chão (Figura 12) e sobre quem poderia ser responsável por tal atitude (Figura 13).

Ao ver panfletos jogados nas ruas de FSA, como lida com a situação?

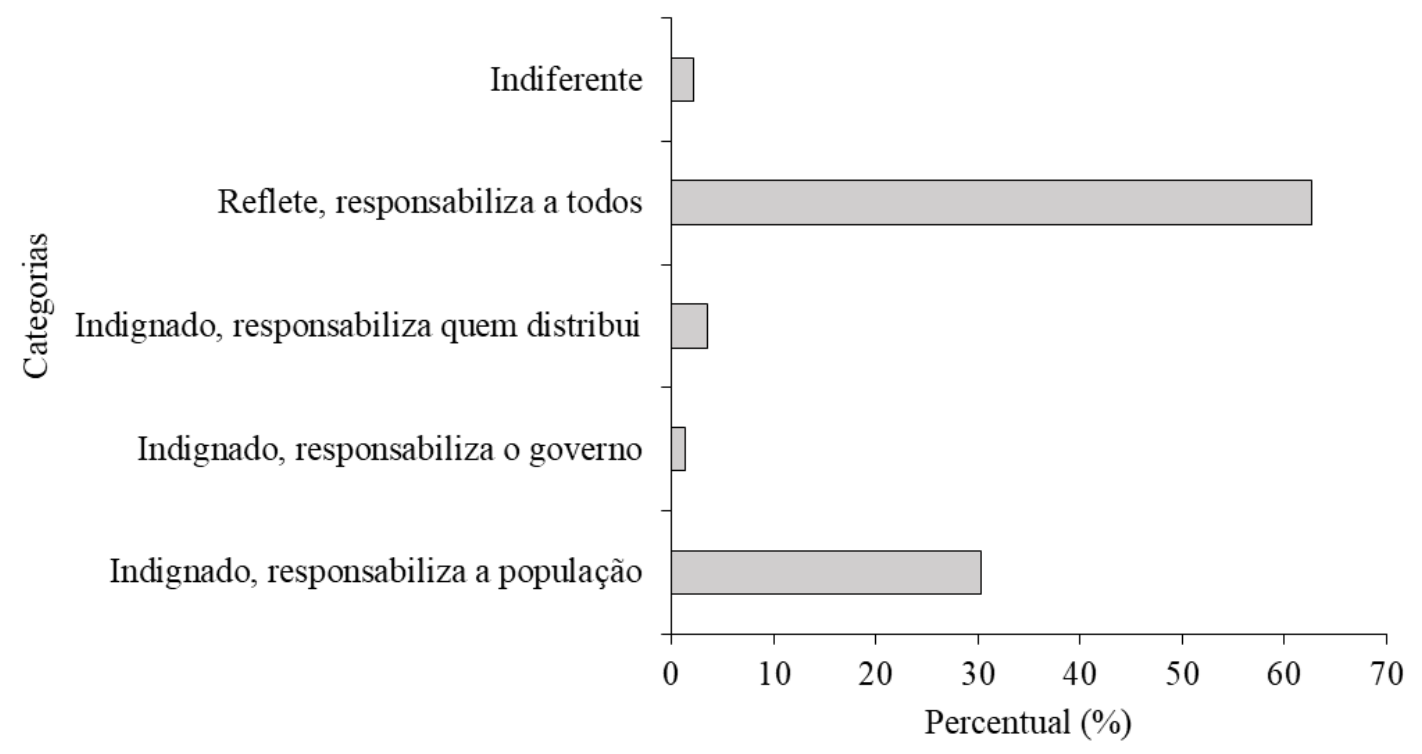

Figura 12. Respostas a pergunta "Ao ver panfletos jogados nas ruas de Feira de Santana, como lida com a situação?" em percentagem. 


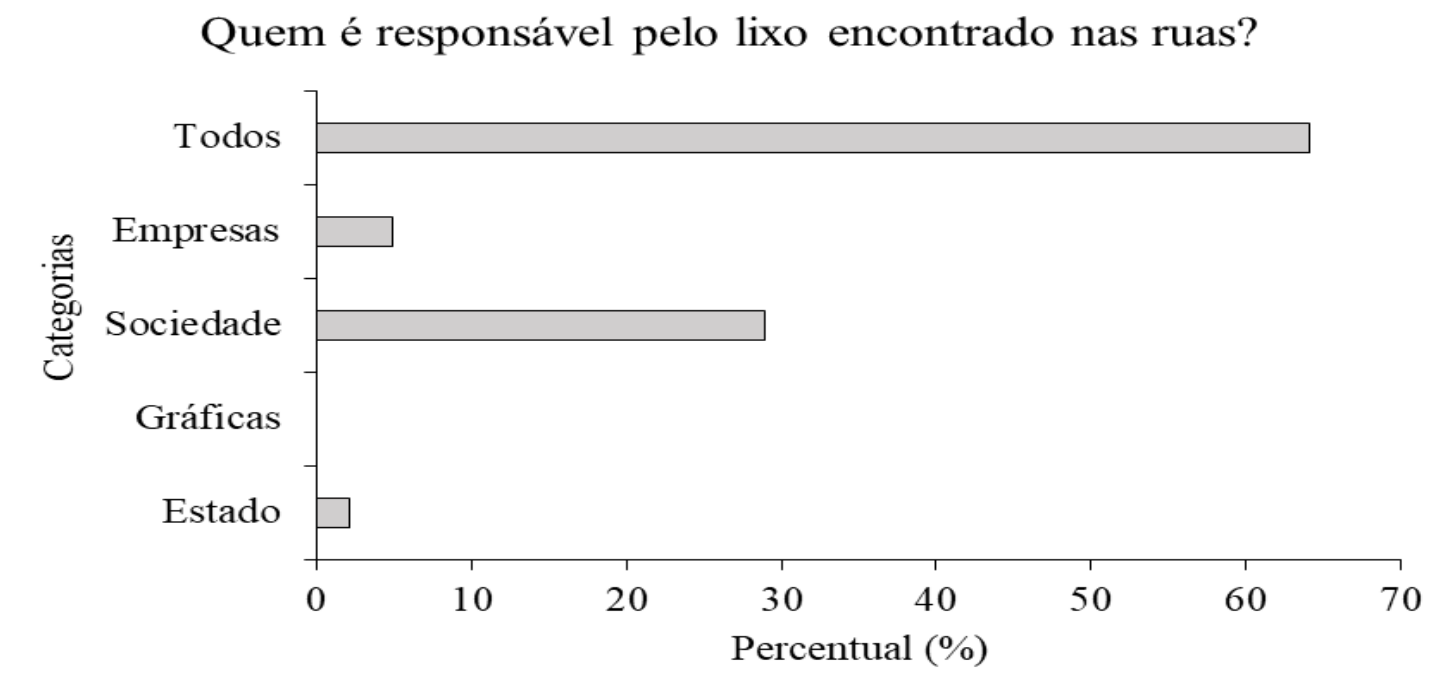

Figura 13. Respostas a pergunta "Quem é responsável pelo lixo encontrado nas ruas de Feira de Santana?" em percentagem.

Foram questionados também sobre qual atitude adotada ao observar alguém jogando panfletos no chão, 69,72\% dos participantes relatam que ficam indignados e refletem sobre, $19 \%$ não se espantam mais, já que é bastante comum a ação, 9,86\% ficam indignados e advertem quem praticou o ato e 1,41\% se dizem indiferentes ao fato. Ao serem indagados sobre qual a postura adotada ao ver alguém distribuindo panfletos, as respostas foram diversas (figura 15). No geral, os participantes parecem não considerar a panfletagem indispensável $(77,5 \%)$ e dizem conhecer outros mecanismos de divulgação que substituem a panfletagem $(90,91 \%)$. Os participantes dizem utilizar com frequência, para se manter atualizado, a internet $(90,14 \%)$ e a televisão e/ou o rádio $(9,86 \%)$, não mencionam neste tópico a utilização dos panfletos, revistas ou jornais, ou outros meios.

Qual a sua atitude ao ver alguém distribuindo panfletos?

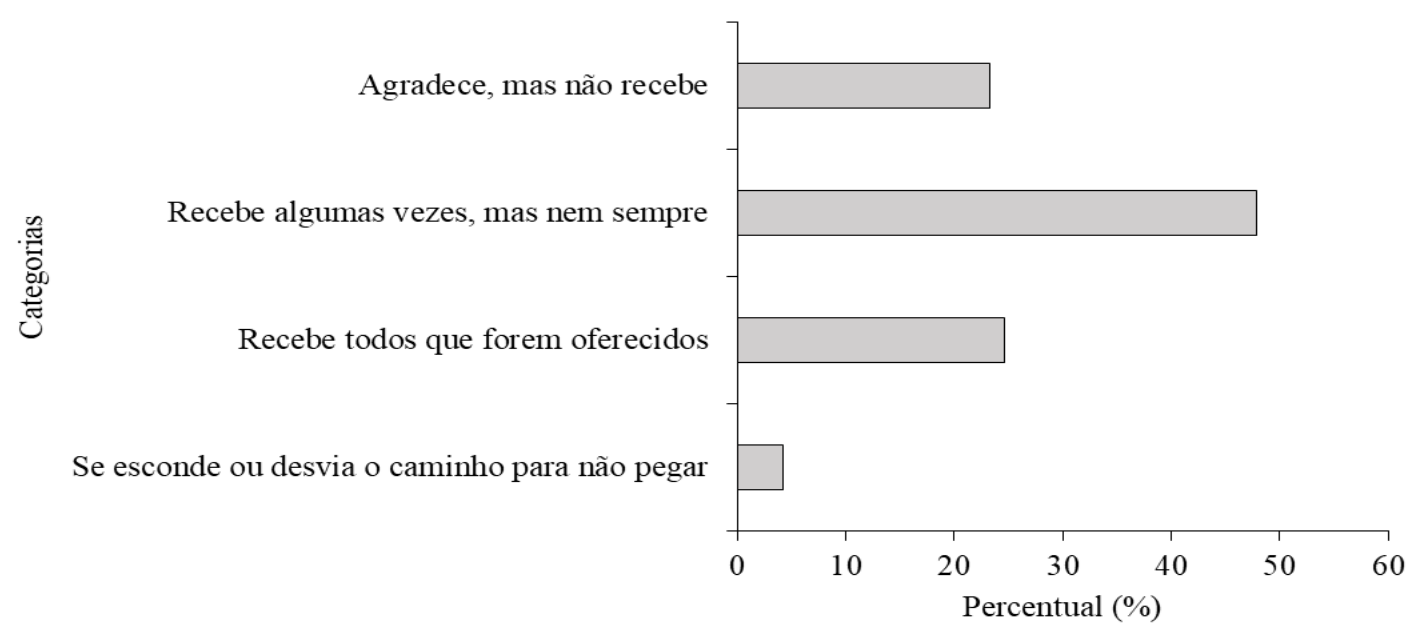

Figura 14. Respostas a pergunta "Qual a sua atitude ao ver alguém distribuindo panfletos?" em percentagem. 
As percepções apontadas acima caracterizam a posição dos munícipes participantes em relação à panfletagem no município. É evidente a precisa percepção que os indivíduos evidenciam sobre o assunto, verifica-se, de forma mais acurada, nas respostas as questões abertas apontadas a seguir. No quesito sobre a responsabilidade do lixo encontrado nas ruas, tem-se um bom nível de percepção por parte dos participantes, onde 64,08\% dos entrevistados afirmam que "todos" são responsáveis pelo lixo encontrado nas ruas. Pode-se inferir que se trata de uma posição consciente do meio que habitam e de co-responsabilização. Segundo Carvalho et al. (2012), a co-responsabilização dos indivíduos é essencial para promover um novo tipo de desenvolvimento, um desenvolvimento que torna mais consciente e responsável a atitude de cada um sobre o meio, um desenvolvimento mais sustentável.

Sabe-se que o sucesso financeiro dos empreendimentos depende do investimento em marketing e propaganda, que muitas vezes considera apenas o lucro acerca da divulgação, sendo assim, cabe a todos impor uma postura mais consciente de forma a interferir no processo de qualidade de vida. A responsabilidade pelos resíduos gerados deve ser compartilhada entre empresas, órgãos governamentais e a sociedade (Siqueira e Assad, 2015). Instituídas na Lei no 12.305/2010 (Brasil, 2010), a logística reversa e a responsabilidade compartilhada são estratégias na implantação de um modelo de produção e consumo sustentáveis que responsabilizam a todos pelos resíduos gerados, tanto o gerador, o importador e distribuidor, quanto o comerciante e consumidor do produto (Brasil, 2010; Campos, 2012). Importante e necessária estratégia que responsabiliza e penaliza "todos" que geram os resíduos sólidos, medida que se faz necessária para conscientização e, consequente, controle, embora este caminho ainda não tenha sido construído de fato no Brasil (Brasil, 2010; Campos, 2012).

\section{Descrição de alternativas de marketing ao uso da panfletagem}

Há relatos de estratégias alternativas ao uso da panfletagem (Ma e Reis, 2011; Bedran, 2013; Siqueira e Assad, 2015), entretanto há autores que defendem a panfletagem como mecanismo eficaz e imprescindível a promoção de bens e serviços para aquecer o comércio (Gázquez-Abad e Pérez, 2007; Antón et al., 2011). As respostas aqui relatadas demostram estes diferentes pontos de vista em relação ao uso da panfletagem. Algumas das respostas aos questionamentos abertos foram inseridas aqui na integra:

\section{1) Quais outros mecanismos poderiam ser utilizados como estratégia de marketing?}

"Bike informativa. Propagandas impressas em letras visíveis presas em uma bicicleta" (Participante 17)

"Através da Internet, rádio e etc. Assim, nós temos uma divulgação ampla que de fato não estará prejudicando o meio ambiente." (Participante 24)

"Redes sociais e aplicativos móveis. Com a popularização da internet, a divulgação através da mesma pode alcançar maior quantidade de pessoas em um tempo mais curto, e, além disso, pode ser mais atrativo, uma vez que podem utilizar também os recursos audiovisuais." (Participante 37)

"Na verdade é um pouco difícil de substituir os planfletos pq (sic) a internet é um meio muito avançado mais nem sempre todos tem acesso e muitas vezes os planfetos (sic) ajudam na comunicação daquela pequena quantidade de pessoas que não tem acesso a internet ou até mesmo quem tem." (Participante 83)

"Panfletagem é um método normalmente utilizado por pequenas empresas (ou algo similar) para que chegue a todo população e que seja algo "imediado" (SIC), mas de pouco serve já que a grande parte ignora os panfletos. Não consigo 
imaginar algo que os substituam e que seja favorável para essas empresas." (Participante 96)

"Através de propagandas em meios de comunicação como TV e rádio. Mas principalmente na internet, pois boa parte dos consumidores ativos tem acesso a mesma ou conhece alguém que tenha e a informa, pois o marketing de boca a boca tbm (sic) funciona (ao meu ver é o mais eficaz)." (Participante 100)

"Publicidade online tem efeito semelhante e maior cobertura" (Participante 109)

“Outdoor, cria uma ampla visualização se colocado em pontos estratégicos que tenho um grande fluxo de pessoas; internet com uso dos aplicativos gratuitos como Instagram que é utilizado por grande parte da população." (Participante 110)

"Existem outros mecanismos, como a internet, mas a panfletagem tem baixo custo e não está restrita pelos filtros de público das redes sociais, por exemplo, podendo atingir pessoas variadas." (Participante 114)

“Propagandas áudio-visuais (que não impressas)” (Participante 124)

“Os panfletos são um dos mecanismos de comunicação utilizados para divulgar um produto. Eles podem ser substituídos por placas, banners ou outros mecanismos em locais de grande circulação." (Participante 135)

\section{Descrição.}

\section{2) Existe experiência de divulgação mais eficiente do que a panfletagem?}

"Sim. Redes sociais, anúncios na televisão e rádio, carro de som, outdoor e cartazes. Panfletagem é o menos eficiente para mim. A abordagem é fria ainda que seja educada, e não gosto do lixo gerado por essa prática." (Participante 8)

"Sim, muitas! Por exemplo, o SMS. Ele engloba muitas pessoas em pouco tempo e por um baixo custo." (Participante 9)

"Internet tem um grande poder de alcance, de modo que várias pessoas podem ter acesso à divulgação" (Participante 31)

"Insta; OLX; cartões em locais adequados para quem se interessa adiquirir (sic); outdoor; Facebook; canais de you tuber (sic)." (Participante 53)

“Ainda não, pois atinge muita gente" (Participante 76)

"Sim. Várias. Mas não para o contexto em que as panfletagens muitas vezes se inserem: de baixo orçamento, de alcance local e para o envolvimento de pessoas que não necessariamente estão conectadas ou seguindo virtualmente o distribuidor do panfleto." (Participante 85)

"Sim. 0 de boca a boca e o de Internet (principalmente divulgação em Instagram e sites) sei de várias lojas aqui em Feira de Santana que fecharam por conta de publicações em Instagram e site, é mais cômodo e de melhor visualização." (Participante 100)

"As divulgações são planejadas de acordo com a expectativa do cliente e o produto a ser anunciado. A eficiência vai depender da relação custo x benefício e o alcance dessa divulgação. Às vezes, a panfletagem pode funcionar melhor que um outdoor ou um carro de som, por exemplo" (Participante 135)

Em ambas as perguntas, os relatos demonstram que os participantes possuem certo domínio sobre o tema e a realidade que o cerca apontando a publicidade online como estratégia eficaz a ser utilizada diante dos avanços tecnológicos. Argumento que corrobora com Gonçalves (2008), que considera que a internet é atualmente um meio de comunicação em massa eficaz para acesso às informações e que agrega um enorme potencial ao processo comunicativo, ao processo de marketing. 0 ciberespaço é apontado 
como o futuro epicentro do mercado, como principal meio da comunicação e da vida social (Lévy, 2001). Alves Junior e Daolio (2017) ratificam como crescente o marketing na internet, processo concomitante a rápida evolução das tecnologias da informação. Segundo os autores, o marketing na internet é vantajoso por possibilitar amplo acesso aos clientes, fácil e rápida comunicação com custo reduzido, sem deixar de mencionar o fator tempo, já que permite a conexão sem intervalos. No entanto, este meio também possui suas limitações, como a vulnerabilidade a fraudes e a restrição do seu uso a certos segmentos sociais que possuam acesso à rede. Apenas $64 \%$ da população brasileira tem acesso à internet (IBGE, 2016), deste modo, a panfletagem ainda é um método de alcance diverso quando se considera os diferentes níveis sociais e a acessibilidade.

\section{Considerações finais}

Percebe-se que é necessário regulamentar a panfletagem no município de Feira de Santana e conscientizar a população e empreendedores com intuito de reduzir a quantidade de panfletos oferecidos pelos panfletistas, diminuir custos com a limpeza urbana e minimizar impactos ambientais. Existem outros meios alternativos à panfletagem eficazes em instigar e persuadir o consumidor. No município de Feira de Santana se faz necessário a adoção de alternativas que antecipem problemas maiores futuros com os resíduos sólidos urbanos.

\section{Conflito de interesses}

Os autores declaram não haver conflito de interesses.

\section{Referências}

ABNT - Associação Brasileira de Normas Técnicas. ABNT NBR 10004: Resíduos Sólidos Classificação. Rio de Janeiro: ABNT, 2004.

ABRELPE - Associação Brasileira das Empresas de Limpeza Pública e Resíduos Especiais. Panorama dos resíduos sólidos no Brasil. São Paulo: ABRELPE, 2016. Disponível em: <http://www.abrelpe.org.br/Panorama/panorama2016.pdf>. Acesso em: 22 fev. 2019.

Alves Junior, W. A.; Daolio, R. P. G. Marketing na Internet: vantagens e desvantagens. Revista Gestão em Foco, v. 9, p. 138-142, 2017.

Anjos, M. C. G. Do necessário diálogo entre direito eleitoral e direito ambiental para redução da poluição do meio ambiente durante o período de propaganda eleitoral: caso do tribunal regional eleitoral do Amazonas. Manaus: Universidade do Estado do Amazonas, 2015. (Dissertação de mestrado).

Antón, R. M.; Aranaz, M. F.; Gallo, P. M.; Marin, M. L. Retail brand building through promotional communication: A study that focuses on category killers promotional flyers. Chinese Business Review, v. 10, n. 3, p. 217-225, 2011. https://doi.org/10.17265/15371506/2011.03.006

Balneário Camboriú. Lei no 2.558, 4 de setembro de 2006. Altera dispositivos da Lei Municipal $n$ o 2.558/2006, que trata sobre a distribuição de propaganda comercial dos logradouros públicos no âmbito do Município de Balneário Camboriú e dá outras providências. Disponível em: <https://leismunicipais.com.br/a/sc/b/balneariocamboriu/lei-ordinaria/2006/264/2643/lei-ordinaria-n-2643-2006-altera-dispositivosda-lei-municipal-n-2558-2006-que-trata-sobre-a-distribuicao-de-propaganda-comercial- 
nos-logradouros-publicos-no-ambito-do-municipio-de-balneario-camboriu-e-da-outrasprovidencias>. Acesso em: 04 fev. 2020.

Bedran, K. M. Processo eleitoral brasileiro: impactos ambientais e o direito ao meio ambiente ecologicamente equilibrado. Belo Horizonte: Escola Superior Dom Helder Câmara, 2013. (Dissertação de Mestrado).

Belo Horizonte. Lei no 10.534 , de 10 de setembro de 2012. Dispõe sobre a limpeza urbana, seus serviços e o manejo de resíduos sólidos urbanos no município e dá outras providências. Disponível em: <https://leismunicipais.com.br/a/mg/b/belo-horizonte/leiordinaria/2012/1053/10534/lei-ordinaria-n-10534-2012-dispoe-sobre-a-limpeza-

urbana-seus-servicos-e-o-manejo-de-residuos-solidos-urbanos-no-municipio-e-da-outrasprovidencias >. Acesso em: 04 fev. 2018.

Bentivegna, F. J. Fatores de impacto no sucesso do marketing boca a boca on-line. Revista de Administração de Empresas, v. 42, n. 1, p. 79-87, 2002. https://doi.org/10.1590/ S0034-75902002000100008

Besen, G. R; Günther, W. M. R.; Rodriguez, A. C.; Brasil, A. L. Resíduos sólidos: vulnerabilidades e perspectivas. In: Vormittag, E. M. P. A. A.; Saldiva, P. Meio ambiente e saúde: o desafio das metrópoles. São Paulo: Ex-Libris, 2010. p. 107-123.

Bezerra, T. M. O.; Feliciano, A. L. P.; Alves, A. G. C. Percepção ambiental de alunos e professores do entorno da Estação Ecológica de Caetés - Região Metropolitana do Recife-PE. Revista Biotemas, v. 21, n. 1, p. 147-160, 2008. https://doi.org/10.5007/21757925.2008v21n1p147

Brasil. Lei no 12.305, de 2 de agosto de 2010. Institui a Política Nacional de Resíduos Sólidos; altera a Lei no 9.605, de 12 de fevereiro de 1998; e dá outras providências. Disponível em: <http://www.planalto.gov.br/ccivil_03/_ato2007-2010/2010/lei/ 112305.htm>. Acesso em: 04 fev. 2018.

Brasil. Lei no 4.737, de 15 de julho de 1965. Institui o Código Eleitoral. Disponível em: <http://www.planalto.gov.br/ccivil_03/LEIS/L4737.htm>. Acesso em: 04 fev. 2020.

Bronnemann, M. R.; Siebert, E. A. Influência das Ações Promocionais no Comportamento do Consumidor de Supermercados. Anais do XXVIII Congresso Brasileiro de Ciências da Comunicação, Rio de Janeiro, 2005.

Campos, H. K. T. Renda e evolução da geração per capita de resíduos sólidos no Brasil.

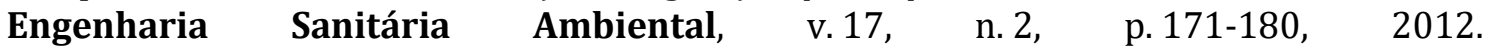
https://doi.org/10.1590/S1413-41522012000200006

Cardoso, D. P.; Pinto, M. M. M. As redes sociais como ferramentas de divulgação de eventos. Fasci-Tech, v. 1, n. 5, p. 30-40, 2011.

Carvalho, E. K. M.; Silva, M. M. P.; Carvalho, J. R. M. Percepção ambiental dos diferentes atores sociais de Vieirópolis, PB. Qualitas Revista Eletrônica, v. 13, n. 1, p. 1-11, 2012. https://doi.org/10.18391/qualitas.v13i1.1462

Carvalho, N. L.; Kersting, C.; Rosa, G.; Fruet, L.; Barcellos, A. L. Desenvolvimento sustentável x desenvolvimento econômico. Revista Monografias Ambientais Santa Maria, v. 14, n. 3, p. 109-117, 2015.

Castanheiro, I. C. A poluição visual: formas de enfrentamento pelas cidades. Revista Internacional de Direito e Cidadania, v. 4, p. 63-78, 2009. 
Christiansen, C.; Bjerre, M. Circulars: A conceptual framework. In: Hansen, F.; Hansen, L. (Eds.). Advertising research in the Nordic countries. Copenhagen: Samfundslitteratur, 2001. p. 244-253.

Correio, V. B. S. Comportamento de compra dos consumidores em mercados de bairro: um estudo na Região de Passo Fundo-RS. Revista de Administração, v. 13, n. 24, p. 22-43, 2015.

Costa, R. G. S.; Colesanti, M. M. A contribuição da percepção ambiental nos estudos das áreas verdes. RA'E GA - 0 Espaço Geográfico em Análise, v. 22, p. 238-251, 2011. https://doi.org/10.5380/raega.v22i0.21774

Demajorovic, J. Da política tradicional de tratamento do lixo à política de gestão de resíduos sólidos: as novas prioridades. Revista de Administração de Empresas, v. 35, n. 3, p. 88-93, 1995. https://doi.org/10.1590/S0034-75901995000300010

Faggionato, S. Percepção ambiental. 2005. Disponível em: <http://educar.sc.usp.br/ biologia/textos/m_a_txt4.html>. Acesso em: 20 fev. 2020.

Farias, T. A poluição eleitoral e o direito ambiental. Revista Jus Navigandi, v. 11, n. 1184, 2006. Disponível em: <https://jus.com.br/artigos/8981>. Acesso em: 5 fev. 2020.

Feira de Santana. 2016. Diário Oficial. Disponível em: <https://www.diariooficial. feiradesantana.ba.gov.br/abrir.asp?edi=331\&p=1 >. Acesso em: 04 fev. 2020.

Ferrara, L. D. As cidades ilegíveis: percepção ambiental e cidadania. In: Oliveira, L.; Del Rio, V. (Orgs.). Percepção ambiental: a experiência brasileira. São Paulo: Studio Nobel, 1996. p. 61-80.

Ferreira, C. R. T. Avaliação da degradação ambiental urbana através da percepção ambiental: o caso do Alto da Bacia do Limoeiro Presidente Prudente. São Paulo: Universidade de Presidente Prudente, 2001. (Dissertação de Mestrado).

Gázquez Abad, J. C.; Pérez, M. S. Eficacia de los folletos publicitarios en el comercio detallista. Revista Española de Investigación de Marketing ESIC, v. 11, n. 2, p. 65-88, 2007.

Gil, A. C. Métodos e técnica de pesquisas sociais. 6. ed. São Paulo: Atlas, 2008.

Gonçalves, D. I. F. Pesquisas de marketing pela internet: as percepções sob a ótica dos entrevistados. Revista de Administração Mackenzie, v. 9, n. 7, p. 70-88, 2008. https://doi.org/10.1590/S1678-69712008000700004

Gouveia, N. Resíduos sólidos urbanos: impactos socioambientais e perspectiva de manejo sustentável com inclusão social. Ciência \& Saúde Coletiva, v. 17, n. 6, p. 1503-1510, 2012. https://doi.org/10.1590/S1413-81232012000600014

Grippi, S. Lixo: reciclagem e sua história - Guia para as prefeituras brasileiras. Rio de Janeiro: Interciência, 2006.

IBGE - Instituto Brasileiro de Geografia e Estatística. 2016. Disponível em: <https://g1.globo.com/economia/tecnologia/noticia/brasil-tem-116-milhoes-de-pessoasconectadas-a-internet-diz-ibge.ghtml>. Acesso em: 24 fev. 2020.

IBGE - Instituto Brasileiro de Geografia e Estatística. 2018. Disponível em: $<$ https://cidades.ibge.gov.br/brasil/ba/feira-de-santana/panorama>. Acesso em: 04 fev. 2020.

INMET - Instituto Nacional de Meteorologia. 2018. Disponível em: <http://www.inmet. gov.br/portal/>. Acesso em: 04 fev. 2020. 
Jacarezinho. Lei Complementar no 44, de 11 de agosto de 2010. Institui o Código de Posturas do Município de Jacarezinho e dá outras providências. Disponível em: $<$ https://leismunicipais.com.br/codigo-de-posturas-jacarezinho-pr>. Acesso em: 04 fev. 2020.

Jacobi, P. R.; Besen, G. R. Gestão de resíduos sólidos em São Paulo: desafios da $\begin{array}{lllll}\text { sustentabilidade. Estudos Avançados, } & \text { v. 25, } & \text { n. 71, } & \text { p. 135-158, } 2011 .\end{array}$ https://doi.org/10.1590/S0103-40142011000100010

Lacerda, N. P.; Souto, P. C.; Dias, R. S.; Souto, L. S.; Souto, J. S. Percepção dos residentes sobre a arborização da Cidade de São José de Piranhas-PB. Revista da Sociedade $\begin{array}{llllll}\text { Brasileira de Arborização Urbana, } & \text { v. 5, } & \text { n. 4, p. 81-95, } 2010 .\end{array}$ https://doi.org/10.5380/revsbau.v5i4. 66319

Lévy, P. A. Filosofia World: o mercado, o ciberespaço, a consciência. São Paulo: Editora 34, 2001.

Lino, K. S.; Santos, C. C.; Santos, D. B.; Matsumoto, M. M.; Cardoso, P. P.; Yamamoto, T. M.; Isabella, G. A promoção por meio de panfletos e a decisão de compra do consumidor: uma pesquisa quantitativa-descritiva. Revista Brasileira de Pesquisas de Marketing, Opinião e Mídia, v. 13, p. 67-87, 2013.

Ma, D. Z. H.; Reis, J. 0 impacto negativo no meio ambiente causado pela panfletagem no restaurante universitário da UNICAMP. Revista Ciências do Ambiente On-Line, v. 7, n. 2, p. 16-19, 2011.

Machado, L. C.; Henkes, J. A. Separação e descarte dos resíduos sólidos urbanos de modo adequado com foco nos resíduos sólidos domésticos. Revista Gestão Sustentável Ambiental, v. 5, n. 1, p. 489-515, 2016. https://doi.org/10.19177/rgsa.v5e12016489-515

Mattar, F. N. Pesquisa de marketing: metodologia, planejamento. 6. ed. São Paulo: Atlas, 2008.

Medeiros, J. G.; Silveira, J. D.; Costa, S. L. Identificação de fatores que interferem na distribuição de panfletos em locais públicos. Psicologia: Teoria e Prática, v. 11, n. 3, p. 82-96, 2009.

Menezes, J. P. C. Percepção ambiental dos visitantes do Parque Municipal Bosque John Kennedy - Araguari, MG. Revista Eletrônica Mestrado Educação Ambiental, v. 26, p. 103-112, 2011.

Mesquita Júnior, J. M. Gestão integrada de resíduos sólidos. Rio de Janeiro: IBAM, 2007.

Miranda, M. J.; Kónya, L. Directing store flyers to the appropriate audience. Journal of Retailing and Consumer Services, v. 14, n. 3, p. 175-181, 2007.

MMA - Ministério do Meio Ambiente. Consumo sustentável: manual de educação. Brasília: Consumers International/MMA/MEC/IDEC, 2005. Disponível em: <http://www.idec.org.br/uploads/publicacoes/publicacoes/Manual_completo.pdf>. Acesso em: 10 fev. 2020.

Oliva Junior, E. F.; Freire, R. S. Os impactos ambientais decorrentes da produção de resíduos sólidos urbanos e seus riscos à saúde humana. Revista Eletrônica da Faculdade José Augusto Vieira, v. 8, p. 158-171, 2013.

Palma, I. R. Análise da percepção ambiental como instrumento ao planejamento da educação ambiental. Porto Alegre: Universidade Federal do Rio Grande do Sul, 2005. (Dissertação de mestrado). 
Prado, M. R. V.; Mattos, V. M. Diagnóstico da gestão dos resíduos sólidos urbanos gerados na Cidade de Poxoréu-MT, Brasil. Uniciências, v. 18, n. 1, p. 5-10, 2014.

Queiroz, C. M. B.; Sá, E. N. C.; Assis, M. M. A. Qualidade de vida e políticas públicas no Município de Feira de Santana. Ciência \& Saúde Coletiva, v. 9, n. 2, p. 411-421, 2004. https://doi.org/10.1590/S1413-81232004000200017

Rodrigues, M. L.; Malheiros, T. F.; Fernandes, V.; Darós, T. D. A. Percepção ambiental como instrumento de apoio na gestão e na formulação de políticas públicas ambientais. Saúde e Sociedade, v. 21, n. 3, p. 96-110, 2012. https://doi.org/10.1590/S0104-12902012000 700009

Santo, S. M. O desenvolvimento urbano em Feira de Santana (BA). Sitientibus, v. 28, p. 9-20, 2003.

Schiffman, L. G.; Kanuk, L. L. Comportamento do consumidor. 6. ed. Rio de Janeiro: LTC, 2000.

Schmidt, M.; Bjerre, M. Can recipients of sales flyers be segmented? International Journal of Advertising, v. 22, n. 3, p. 375-391, 2003. https://doi.org/10.1080/02650487.2003. 11072859

Schossler, B. G.; Morigi, V. J. Sustentabilidade e responsabilidade socioambiental: um estudo na Empresa Florestal de Alimentos S.A. em Lajeado-RS. Revista Destaques Acadêmicos, v. 3, n. 1, p. 17-25, 2011.

Silva, G. D. P.; Coutinho, E. C. Estudo da percepção de poluição visual das propagandas eleitorais e seus impactos na saúde mental humana. Acervo On-Line de Mídia Regional, v. 11, n. 1, p. 41-53, 2016.

Silva, H. A situação etnográfica: andar e ver. Horizontes Antropológicos, v. 15, n. 32, p. 171-188, 2009. https://doi.org/10.1590/S0104-71832009000200008

Silva, S. P. A organização coletiva de catadores de material reciclável no Brasil: dilemas e potencialidades sob a ótica da Economia Solidária. Rio de Janeiro: IPEA, 2017. (Texto para discussão, 2268). Disponível em: <http://www.ipea.gov.br/portal/images/ stories/PDFs/TDs/td_2268.pdf>. Acesso em: 11 fev. 2020.

Siqueira, T. M. O.; Assad, M. L. R. C. L. Composting of municipal solid waste in the State of São Paulo (Brazil). Ambiente \& Sociedade, v. 18, n. 4, p. 235-258, 2015. https://doi.org/10.1590/1809-4422ASOC1243V1842015

Soledade, A. 0.; Anjos, M. C. G. Meio ambiente e processo eleitoral: do necessário diálogo entre direito ambiental e eleitoral. Anais do XXIII Congresso Nacional do CONPEDI Direito Ambiental IV, Florianópolis, 2014. Disponível em: <http://publicadireito.com.br/ publicacao/ufpb/livro.php?gt=239>. Acesso em: 10 fev. 2018.

Sorrentino, M.; Trajber, R.; Ferraro Junior, L. A. Educação ambiental como política pública. Educação e Pesquisa, v. 31, n. 2, p. 285-299, 2005. https://doi.org/10.1590/S151797022005000200010

Vieira, H. C.; Castro, A. E.; Schuch Júnior, V. F. 0 uso de questionários via e-mail em pesquisas acadêmicas sob a ótica dos respondentes. Anais do XIII SEMEAD - Seminários em Administração, São Paulo, 2010. Disponível em: <http://www.ead.fea.usp.br/ semead/13semead/resultado/trabalhosPDF/612.pdf>. Acesso em: 10 fev. 2018. 
Zanta, V. M.; Ferreira, C. F. A. Gerenciamento integrado de resíduos sólidos urbanos. In: Castilhos Junior, A. B. (Coord.). Resíduos sólidos urbanos: aterro sustentável para municípios de pequeno porte. Rio de Janeiro: ABES, RIMA, 2003. p. 1-18.

(CC) Anformação da Licença: Este é um artigo Open Access distribuído sob os termos da Licença Creative Commons seja devidamente citada. 